\title{
RADIOCARBON DATES FROM THE PLEISTOCENE FOSSIL DEPOSITS OF SAMWEL CAVE, SHASTA COUNTY, CALIFORNIA, USA
}

\author{
Robert S Feranec ${ }^{1,2} \bullet$ Elizabeth A Hadly $^{1} \bullet$ Jessica L Blois $^{1} \bullet$ Anthony D Barnosky $^{3} \bullet$ \\ Adina Paytan 4
}

ABSTRACT. Dates obtained from the collagen of 5 mammals from the fossil deposits of Samwel Cave, Shasta County, California, USA, show emplacement during the last glacial maximum. These dates support the assignment of the fauna to the late Pleistocene. The Samwel Cave deposits currently do not appear to be stratified.

\section{INTRODUCTION}

Within California, much of what we know about the late Pleistocene derives from understanding the abundant fossil deposits of southern California, such as the famous Rancho La Brea tar pits (Miller 1971; Stock 1992). The late Pleistocene deposits in northern California have been studied to a much lesser extent (Sinclair 1903, 1905; Furlong 1906; Graham 1959; Payen and Taylor 1976). Two notable sites in northern California are Samwel Cave (SC) and Potter Creek Cave (PCC), located in Shasta County. These 2 fossil localities are particularly interesting because of the high diversity represented at each site, presence of both extinct and extant mammal species, and location within $5 \mathrm{~km}$ of each other near major climatic and vegetation boundaries. Comparison of the fauna within the 2 localities may provide a unique opportunity to understand the ecology of mammals near the end of the Pleistocene. It is therefore important to determine how these 2 sites relate to one another chronologically. Radiocarbon dates have been published previously from specimens from PCC (Taylor 1975; Payen and Taylor 1976; Meltzer and Mead 1983), but no such analysis has been completed for Samwel Cave. It is the aim of this study to obtain ${ }^{14} \mathrm{C}$ dates from the fauna of Samwel Cave.

\section{BACKGROUND}

Samwel Cave (Figure 1) is located on the eastern edge of the McCloud River arm of Lake Shasta in the McCloud Limestone at 460 m elevation. Excavation of the cave commenced in the early 1900s by a team from the University of California in an effort to find presence of the first humans in the state (Furlong 1906). Two main excavations were conducted from 1903-1906 in Chambers One and Two by a group including E L Furlong, J C Merriam, and W J Sinclair (Figure 2) (Furlong 1906). Within the chambers, fossils were exhumed in $4-\mathrm{ft}^{2}$ pits dug in 10-inch levels. The sediments within Chambers One and Two were similar. At its deepest, the excavation was $2.5 \mathrm{~m}$. The bottommost layer is a mix of earth and breccia $(30-140 \mathrm{~cm})$, overlain by a flowstone $(2.5-10 \mathrm{~cm})$. Breccia overlays the flowstone $(60 \mathrm{~cm})$ and is covered by gravel $(10-45 \mathrm{~cm})$, which is capped by a flowstone $(3 \mathrm{~cm})$ and a thin layer of reddish clay (Furlong 1906). Many specimens from the excavations are identifiable to the square and depth from which they were obtained. Fossils were found throughout the strata and elsewhere in the cave. Other excavations during the late 1950s were conducted in the Pleistocene Hall (Figure 2). In total, nearly 1000 specimens were collected, representing at least 13 bird and 45 mammal species (Table 1). The collected specimens are housed at the University of California Museum of Paleontology (UCMP).

\footnotetext{
${ }^{1}$ Department of Biological Sciences, Stanford University, Stanford, California 94305, USA.

${ }^{2}$ Current address: New York State Museum, 3140 Cultural Education Center, Albany, New York 12230, USA.

Corresponding author. Email: rferanec@mail.nysed.gov.

${ }^{3}$ Department of Integrative Biology, University of California, Berkeley, California 94720, USA.

${ }^{4}$ Department of Geological and Environmental Science, Stanford University, Stanford, California 94305, USA.
} 


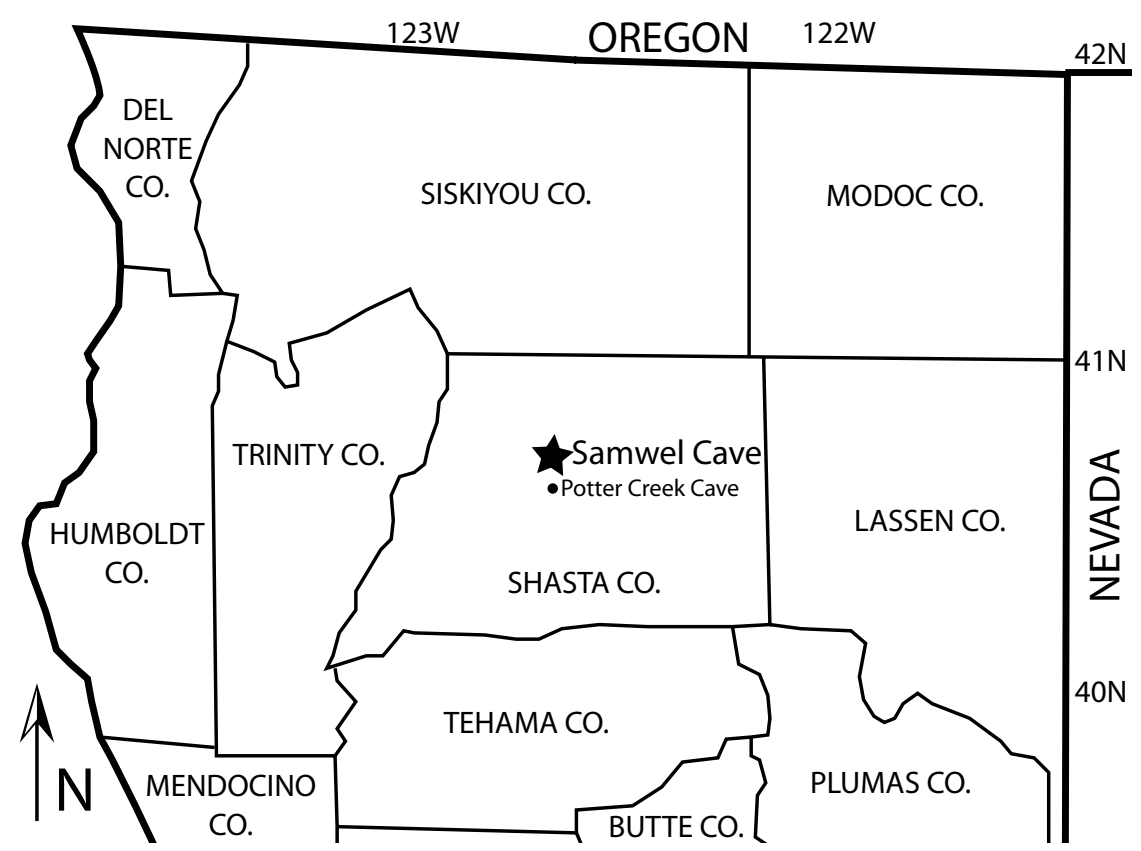

Figure 1 Location of Samwel Cave ( $\star$ ) in Shasta County, California, USA. Also, note the location of Potter Creek Cave to the south.

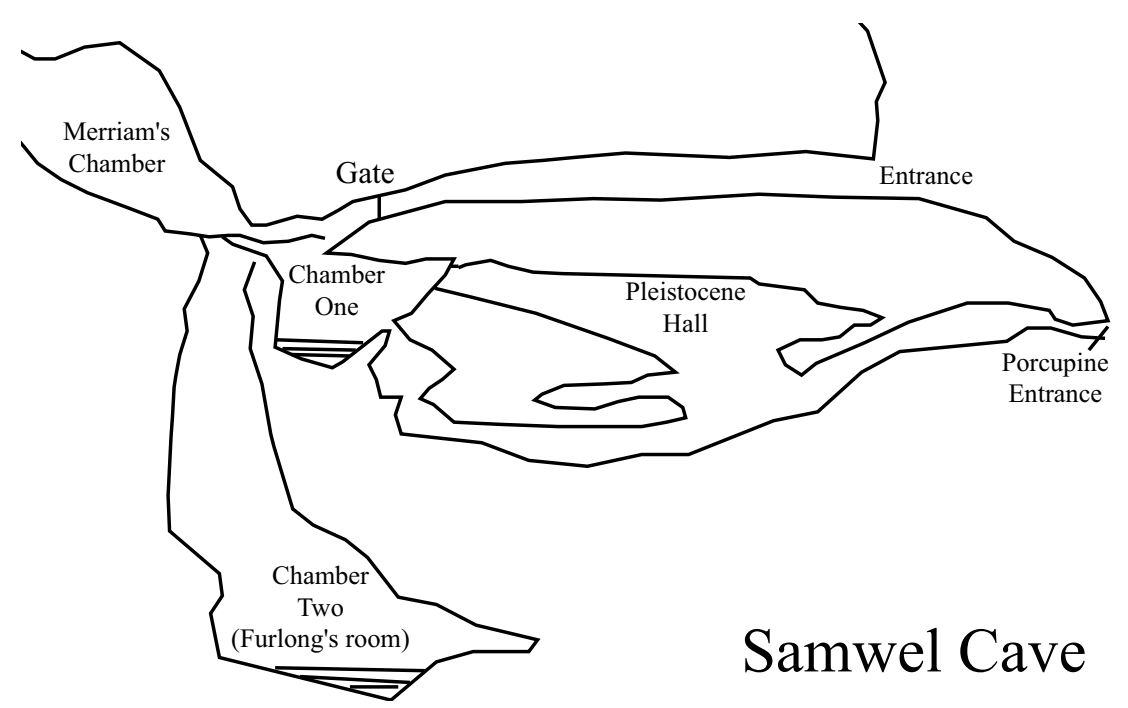

Figure 2 Cross-sectional view of Samwel Cave. The dated specimens come from Chamber Two, "Furlong's Room."

\section{METHODS}

The ancient bone samples were obtained from the vertebrate paleontology collections at the UCMP. Five different specimens from Chamber Two were analyzed including both large and small species. Preparation procedures generally follow Brown et al. (1988) and Bronk Ramsey et al. (2004). Briefly, samples were first decalcified using $0.5 \mathrm{~N} \mathrm{HCl}$ to obtain collagen. Collagen was then gelati- 
Table 1 Mammalian species list for Samwel Cave. Faunal deposits include 45 mammal species. Symbols: $\dagger$, extinct;

$\$$, historic extirpation.

\begin{tabular}{|c|c|}
\hline 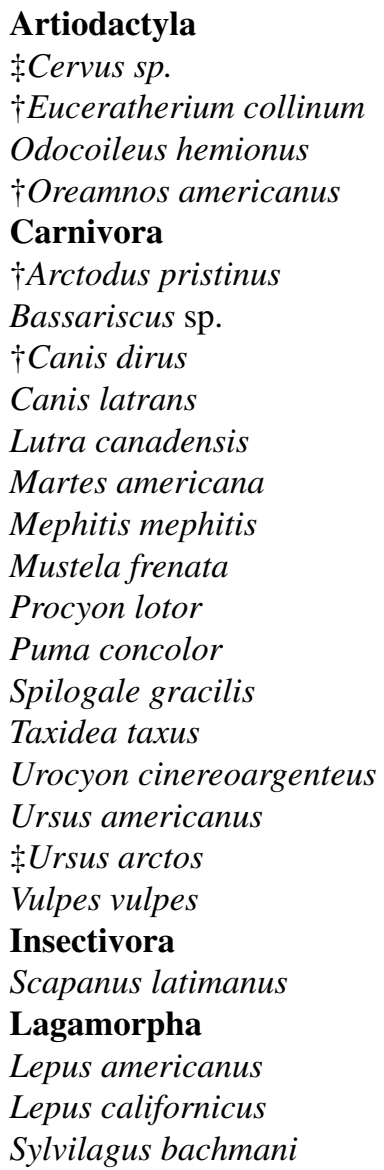 & $\begin{array}{l}\text { Perissodactyla } \\
\dagger \text { Equus sp. } \\
\text { Proboscidea } \\
\dagger \text { Mammuthus primigenius } \\
\text { Rodentia } \\
\text { Aplodontia rufa } \\
\text { Castor canadensis } \\
\text { Erethizon dorsatum } \\
\text { Glaucomys sabrinus } \\
\text { Marmota sp. } \\
\text { Microtus californicus } \\
\text { Neotoma cinerea } \\
\text { Neotoma fuscipes } \\
\text { Peromyscus maniculatus } \\
\text { Sciurus griseus } \\
\text { Spermophilus beecheyi } \\
\text { Spermophilus lateralis } \\
\text { Tamias sp. } \\
\text { Tamiasciurus douglasii } \\
\text { Thomomys bottae } \\
\dagger \text { Thomomys microdon } \\
\text { Thomomys monticola } \\
\text { Xenarthra } \\
\dagger \text { Megalonyx sp. } \\
\dagger \text { Nothrotheriops shastensis }\end{array}$ \\
\hline
\end{tabular}

nized at $58^{\circ} \mathrm{C}$ for $16 \mathrm{hr}$. The gelatin solution was filtered to remove any remaining solids. The solution was then ultra-filtered to remove the $30-\mathrm{kD}$ fraction, and the $30-\mathrm{kD}$ fraction was then lyophilized. The freeze-dried collagen appeared yellowish-white in color and cotton-ball-like for each sample. The freeze-dried collagen samples were then graphitized for AMS analysis. Percent yields for the samples ranged from $9 \%$ to $48 \%$ (Table 2). Bone collagen samples were analyzed at the CAMS facility at Lawrence Livermore National Laboratory and calibrated using CALIB 5.0 (Stuiver et al. 2005).

\section{RESULTS AND DISCUSSION}

Five dates were obtained from the Samwel Cave specimens (Table 2). The samples span the last glacial maximum (LGM) (Yokoyama et al. 2000). Three of the samples range from 17,100-17,900 cal $\mathrm{BC}$, while the other 2 range from 21,300-23,600 cal BC. The bone dates do not follow in stratigraphic order, as the date from $50.8 \mathrm{~cm}\left(20^{\prime \prime}\right)$ down in Section 5 is older than the date obtained from $76.2 \mathrm{~cm}\left(30^{\prime \prime}\right)$ down in Section 4. So, although the deposits were excavated as if the sediment was stratified, the data currently do not support stratified deposition. 


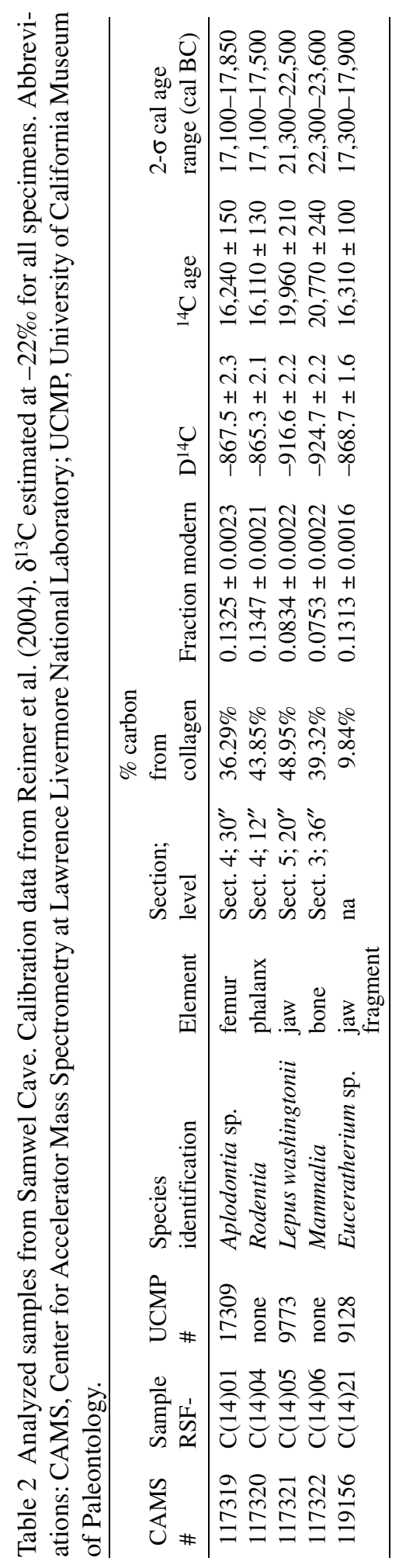


Based on the mammalian fossil assemblage present and the number of extinct animals at SC and PCC, previous studies suggested that the SC faunal deposits were younger than the PCC deposits (Taylor 1975; Payen and Taylor 1976; Meltzer and Mead 1983). The dates available for the PCC fauna are all Holocene in age. The oldest date provided is $8250 \pm 330 \mathrm{BP}$ (cal BC 8178-6457), which is surprising since it comes from the extinct ungulate Euceratherium. This taxon is proposed to have gone extinct before the end of the Pleistocene (Barnosky et al. 2004). Either this young date on Euceratherium is suspect or northern California acted as a refugium for the species. Because it is unclear what fraction of the Euceratherium bone was analyzed to obtain the ${ }^{14} \mathrm{C}$ date, using the reliability rating system of Meltzer and Mead $(1983,1985)$ and Mead and Meltzer (1984), the Euceratherium specimen would receive a score of 7 and be considered unreliable. Because of recent techniques in what portion of collagen is analyzed and how it is prepared (Meltzer and Mead 1985), the dates presented herein from Samwel Cave would be given a score of 8 or 9 and are considered reliable.

From the current data, it appears that the previous suggestions that the $\mathrm{SC}$ fauna are younger than the PCC fauna are incorrect. However, if the Euceratherium date is in fact anomalous, the PCC fauna would be expected to occur prior to the LGM. Additional analyses of the PCC fauna are currently underway to reevaluate the chronology of deposition at the site.

\section{ACKNOWLEDGMENTS}

We would like to thank P Holroyd for permission to sample and analyze these specimens. Without the help of T Guilderson and P Zermeño from the Lawrence Livermore National Laboratory, this research could not have been completed. Funding was obtained from NSF grant EAR-0310337 to EAH and AP.

\section{REFERENCES}

Barnosky AD, Koch PL, Feranec RS, Wing SL, Shabel AB. 2004. Assessing the causes of Late Pleistocene extinctions on the continents. Science 306(5693):70 5 .

Bronk Ramsey C, Higham T, Bowles A, Hedges R. 2004. Improvements to the pretreatment of bone at Oxford. Radiocarbon 46(1):155-63.

Brown TA, Nelson DE, Vogel JS, Southon JR. 1988. Improved collagen extraction by modified Longin method. Radiocarbon 30(2):171-7.

Furlong EL. 1906. The exploration of Samwel Cave. American Journal of Science 22:235-47.

Graham R. 1959. Additions to the Pleistocene fauna of Samwel Cave, California. I. Canis lupus and Canis latrans. Cave Studies 10:54-67.

Mead JI, Meltzer DJ. 1984. North American late Quaternary extinctions and the radiocarbon record. In: Martin PS, Klein RG, editors. Quaternary Extinctions: A Prehistoric Revolution. Tucson, Arizona, USA: University of Arizona Press. p 440-50.

Meltzer DJ, Mead JI. 1983. The timing of Late Pleistocene mammalian extinctions in North America. Quaternary Research 19(1):130-5.

Meltzer DJ, Mead JI. 1985. Dating late Pleistocene extinctions: theoretical issues, analytical bias, and substantive results. In: Mead JI, Meltzer DJ, editors. Environment and Extinctions: Man in Late Glacial North
America. Orono, Maine, USA: University of Maine, Center for the Study of Early Man. p 145-73.

Miller WE. 1971. Pleistocene vertebrates of the Los Angeles Basin and vicinity (exclusive of Rancho La Brea). Bulletin of the Los Angeles County Museum of Natural History 10:1-124.

Payen LA, Taylor RE. 1976. Man and Pleistocene fauna at Potter Creek Cave, California. Journal of California Anthropology 3(1):51-8.

Sinclair WJ. 1903. A preliminary account of the exploration of the Potter Creek Cave, Shasta County, California. Science 17:708-12.

Sinclair WJ. 1905. New mammalia from the Quaternary caves of California. University of California Publications in Geology 4:145-61.

Stock C. 1992. Rancho La Brea. A record of Pleistocene life in California. Los Angeles County Museum [LACM] Science Series 37:1-79.

Stuiver M, Reimer PJ, Reimer R. 2005. CALIB 5.0. URL: http://calib.qub.ac.uk/calib/.

Taylor RE. 1975. UCR radiocarbon dates II. Radiocarbon 17(3):396-406.

Yokoyama Y, Lambeck K, De Deckker P, Johnston P, Fifield LK. 2000. Timing of the last glacial maximum from observed sea-level minima. Nature 406(6797): 713-6. 